\title{
Status of Foodservice Sanitary Management in Family Child Care Center and Effect of Management Support
}

\author{
Joo-Eun Lee
}

\begin{abstract}
This study intended to examine the status of the foodservice sanitary management in 185 family child care centers and evaluate the effect after receiving the service of Center for Children's Foodservices Management (CCFM). The compliance rate of the personal sanitary management area was $55.7 \%$ showing low out of 6 foodservice sanitary areas and in the detailed item, using the dishcloth, glove and apron separately for cooking and cleaning was $19.5 \%$, wearing sanitary apron and gloves when distributing food was $46.5 \%$ and adequate temperature management of refrigerator and freezer was $54.1 \%$ showing low compliance rate. After the first and second sanitary management supports of CCFM, the significant improvement was found in 21 items out of total 27 items $(p<0.05, p<0.01, p<0.001)$, and the total score was increased from 69.70 point significantly to 80.63 points after the first sanitary education and to 84.98 points after the second education (out of full score of 100 points).Particularly, judging by that while there were the items that have been improved rapidly after the first visit, there were the items that were improved significantly after receiving the second support than the first support, it needs the continuous sanitary education. Many family child care centers have yet to receive support from the CCFM. Therefore, more child care centers should receive the support of the CCFM constantly.
\end{abstract}

Keywords : CCFM, Family Child Care Centers, Foodservice, Sanitation

\section{INTRODUCTION}

Among the children under 5 years of age in South Korea, the proportion of the children attending the child care center is $54.1 \%$ and out of them, the private child care center occupied $51.4 \%$ the highest and followed by the family child care center $(22.6 \%)$, national and public child care center $(12.1 \%)$ and the child care center of social welfare foundation $(6.8 \%)$ in order [1]. The family child care center, which has second the 20 children or less and has low average age as it has many children with age of 2 or less [2]. The children attending the child care center has higher risk of infection than being raised at home and particularly, the children with the ages of 2 or less has 2 times higher infection rate compared to the children with the age between 2 and 4[3,4].However, since the research that investigated the sanitary condition of the child care center reported that not only the kitchen equipment and tools that prepare and cook the food but also the hands of employees were contaminated by the microorganism, the

\section{Revised Manuscript Received on July 22, 2019.}

Joo-Eun Lee, Dept. of Food and Nutrition, Seowon University and Director of Center 3 for children's foodservice management in Cheongju City, Chungbuk, South Korea. joody88@hanmail.net highest proportion of children's population, is operated with

sanitary management and the precaution for cross-contamination are needed desperately $[5,6,7]$.

To ensure the healthy dietary life of the children vulnerable to the infection by microorganism, FDA in South Korea established and operates the Center for Children's Foodservice Management (CCFM) from 2011. CCFM supports the foodservice sanitary and nutrition management for the child care center, kindergarten and child welfare center providing foodservice for less than 100 persons that do not have legal obligation to hire the nutritionist. First, the nutritionists of the Center inspect the sanitary condition in the kitchen, verify the nutrition management status by visiting regularly the child care center for the foodservice site and perform the sanitary and nutrition education fit to the cook, director of the center, parents and children. Besides, they prepare and post the menu, standard recipe, education materials, newsletter, etc. on the homepage and perform the collective education by subject group such as the cook, director of the center, parents and children [8].

Since the response of the child care center for the operation of Center for Children's Foodservice Management was favorable and the social benefits of the center's support were 11-15 times higher compared to the investment [9], It started by opening 12 centers in 2011 but it was increased to 219 centers in March, 2019 operating the center for children's foodservice management almost all the administrative units (city and country) across the country [10].In January, 2017, KFDA announced officially that $60 \%$ of children in children foodservice centers having less than 100 children in our country are supported by the Center for Children's Foodservice Management [11]. However, out of the children foodservice centers having less than 100 children, the small size of children foodservice centers having 20 children or less do not have much benefits from the Center for Children's Foodservice Management compared to the large size of child care center or kindergarten [12]. Therefore, this study intended to examine the status of the foodservice sanitary management in family child care centers, which are the member of the Center for Children's Foodservice Management exclusive for small size of child care center having 20 children or less, before the support of the Center and prepare the basic data so that more family child care centers can get the benefits from the center for children's foodservice management by evaluating the effects after receiving the support of foodservice sanitary management. 


\section{METHODS}

\section{A. Research subjects and duration}

This study was performed with 185 family child care centers, the member of the Center for Children's Foodservice Management dedicated to small child care centers in Cheongju City and the dietitians of Center for Children's Foodservice Management visited and inspected the foodservice site of the family child care centers personally from February, 2016 to June, 2017.

\section{B. Survey contents and method}

This study used the 'small children's foodservice sanitation and safety management checklist' shown in Guideline [8] of Center for Children's Foodservice Management in our country when inspecting the foodservice site of family child care center. The checklist used for site inspection was composed of 27 items, which were classified into 6 areas. 6 areas include the environment management such as facilities, personal hygiene management, food ingredients and raw material management, cooking process management, food ingredient storage management, other meal service management.

Generally, the dietitians from Center for Children's Foodservice Management visit the member child care center, perform required sanitary education after inspecting the conditions of foodservice site, first, and provide the supportive products, too. In this study, they visited the sanitary management condition of the foodservice site having the foodservice sanitary management checking list at first visit after joining as a member of Center and performed the education immediately after the inspection. They made the second and third visits with the interval of 6 months and inspected the site management condition changed after previous education. They scored 27 foodservice management items according to the points shown in guideline and compared the scores before and after the first and second foodservice sanitary management support. The first February and June of 2016, the second inspection and sanitary education were performed between July and November of 2016, and the third inspection and sanitary education were performed between February and June of 2017. The sanitary education was performed for the cooks and director of the center focusing on the overall contents of checklist and the parts with insufficient management immediately after finishing the site inspection and 1 hour to 1 hour and half was taken for site inspection and education time. The support products delivered to the child care center were 3 kinds; hand cleaner for the first visit; apron and dishcloth for second visit.

\section{Data Analysis}

For the statistical analysis, SPSS ver. 18.0 for windows(Statistical Package for Social Science, SPSS Inc, Chicago, IL, USA)was used. The frequency analysis was performed for the general aspects of the subject child care centers and the percentage (compliance rate) of the foodservice management status was examined based on the first and second sanitary inspection results. Then, the difference of average scores of first, second and third sanitary inspection and sanitary education were performed between

inspection was examined by performing the p-paired t-test for the average scores between the first and second and between the second and third.

\section{RESULTS}

\section{A. General aspects of research subjects}

The general aspects for research subjects are shown in Table 1.The research subjects were corresponded to the small size of children foodservice having 20 children or less, the child care center having children between 16 and 20 were 82 the most, and for the number of teachers, the child care centers having 5 teachers were $58(31.3 \%)$ the most. The child care centers having 1 cook were $131(70.8 \%)$ out of total 185 and the child care centers that do not have cook and the director cooks instead were $54(29.2 \%)$. The child care centers with cooking career of the director or cook under 1 year were91 (49.2\%) occupying the highest proportion. For the place to have meal, the classroom was used by 150 centers $(81.1 \%)$ the most and the child care centers that have received the evaluation and certification of Ministry of Health and Welfare were $158(85.4 \%)$.

Table 1. General characteristics of the family child care centers

\begin{tabular}{|c|c|c|c|}
\hline \multicolumn{4}{|c|}{ 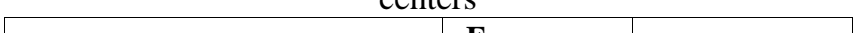 } \\
\hline \multicolumn{2}{|c|}{ Category } & $\begin{array}{l}\text { Frequency } \\
\text { (N) }\end{array}$ & Percentage (\%) \\
\hline \multirow{4}{*}{ Number of child } & $1-5$ & 7 & 3.8 \\
\hline & $5-10$ & 33 & 17.8 \\
\hline & $11-15$ & 63 & 34.1 \\
\hline & $16-20$ & 82 & 44.3 \\
\hline \multirow{7}{*}{$\begin{array}{c}\text { Number of } \\
\text { teachers }\end{array}$} & 1 & 2 & 1.1 \\
\hline & 2 & 18 & 9.7 \\
\hline & 3 & 39 & 21.1 \\
\hline & 4 & 50 & 27.0 \\
\hline & 5 & 58 & 31.3 \\
\hline & 6 & 14 & 7.6 \\
\hline & 7 & 4 & 2.2 \\
\hline \multirow{2}{*}{$\begin{array}{c}\text { Number of } \\
\text { foodservice } \\
\text { employee }\end{array}$} & $0^{*}$ & 54 & 29.2 \\
\hline & 1 & 131 & 70.8 \\
\hline \multirow{5}{*}{$\begin{array}{c}\text { Working period } \\
\text { of } \\
\text { foodservice } \\
\text { employee } \\
\text { (or directors' } \\
\text { cooking } \\
\text { periods) } \\
\text { (years) }\end{array}$} & $<1$ & 91 & 49.2 \\
\hline & $1 \leq-<3$ & 39 & 21.1 \\
\hline & $3 \leq-<5$ & 30 & 16.2 \\
\hline & $5 \leq-<7$ & 21 & 11.4 \\
\hline & $7 \leq-<10$ & 4 & 2.1 \\
\hline \multirow{3}{*}{ Drinking water } & $\begin{array}{c}\text { Using water } \\
\text { purifier }\end{array}$ & 133 & 71.9 \\
\hline & $\begin{array}{l}\text { Boiling tap } \\
\text { water }\end{array}$ & 45 & 24.3 \\
\hline & Others & 7 & 3.8 \\
\hline \multirow{3}{*}{ Place for meal } & Classroom & 150 & 81.1 \\
\hline & Dining room & 14 & 7.6 \\
\hline & $\begin{array}{l}\text { Classroom + } \\
\text { Dining room }\end{array}$ & 21 & 11.3 \\
\hline National & Yes & 158 & 85.4 \\
\hline
\end{tabular}




\begin{tabular}{|c|c|c|c|}
\hline $\begin{array}{c}\text { accredited } \\
\text { facilities }\end{array}$ & No & 27 & 14.6 \\
\hline \multicolumn{2}{|c|}{ Total } & 185 & 100 \\
\hline
\end{tabular}

* Director cooks instead of foodservice employee.

\section{B. Status of Sanitary Management in Family Child Care Center before Foodservice Management Support}

The sanitary management status before supporting the foodservice management in the family child care center by the Center for Children's Foodservice Management are shown in Table 2. The foodservice sanitary management status was shown with the compliance rate of 185 subject child care centers for the each item of checklist. Out of the 6 areas of the foodservice sanitary management, the compliance rate of the personal hygiene management area was $55.7 \%$ showing low and in the detailed items, the item 'the food ingredients that do not cook with heating are disinfected with chlorine and washed sufficiently' was $8.1 \%$ showing the lowest compliance rate followed by the item 'use different dishcloth, glove and apron separately for the cooking and cleaning' (19.5\%), the item 'the unmarked raw material and foods are not used' (23.2\%), the item 'wearing sanitary clothing when distributing the foods' $(46.5 \%)$ and 'appropriate temperature management of freezer and refrigerator' $(54.1 \%)$.

Table 2. The Sanitary management status of family childcare centers before the support

\begin{tabular}{|c|c|c|}
\hline & $\begin{array}{c}\text { Obeying } \\
\text { no. } \\
(\mathbf{N})\end{array}$ & $\begin{array}{c}\text { Obeying } \\
\text { rate } \\
(\%)\end{array}$ \\
\hline \multicolumn{3}{|c|}{ <The facilities management area for environment $>$} \\
\hline $\begin{array}{l}\text { 1. The floor, wall, ceiling, waste container, ventilation, } \\
\text { mothproof facilities are managed cleanly. }\end{array}$ & 141 & 76.2 \\
\hline $\begin{array}{l}\text { 2. The room is well lighted up and the indoor } \\
\text { environment is maintained cleanly by mechanical } \\
\text { ventilation. }\end{array}$ & 172 & 93.0 \\
\hline 3. The screen is installed on the window for mothproof. & 180 & 97.3 \\
\hline $\begin{array}{l}\text { 4. The kitchen is equipped to disinfect the tableware and } \\
\text { to cook sanitarily. }\end{array}$ & 169 & 91.4 \\
\hline \multicolumn{3}{|l|}{\begin{tabular}{|l|} 
<The personal hygiene area $>$ \\
\end{tabular}} \\
\hline 5. The cook is receiving health checkup once a year. & 109 & 58.9 \\
\hline $\begin{array}{l}\text { 6. The cook pays thorough attention to the personal } \\
\text { hygiene. (including wearing disinfected garment, } \\
\text { sanitary cap and sanitary glove and cleaning hands after } \\
\text { contaminated work, etc.) }\end{array}$ & 89 & 48.1 \\
\hline $\begin{array}{l}\text { 7. The cook doesn't wear the accessories such as earring, } \\
\text { ring, manicures when cooking. }\end{array}$ & 111 & 60.0 \\
\hline \multicolumn{3}{|c|}{\begin{tabular}{|c|} 
<The food ingredient and raw material management area> \\
\end{tabular}} \\
\hline 8. The unauthorized raw material and food are not used & 121 & 65.4 \\
\hline $\begin{array}{l}\text { 9. The spoiled raw material and food are not used or } \\
\text { stored. }\end{array}$ & 173 & 93.5 \\
\hline 10. The unmarked raw material and food are not used. & 43 & 23.2 \\
\hline $\begin{array}{l}\text { 11. The raw material or food expired the self life is not } \\
\text { used or stored for the purpose of cooking' }\end{array}$ & 124 & 67.0 \\
\hline $\begin{array}{l}\text { 12. In case of using the water supply system, the water is } \\
\text { used after boiling or in case of using water purifier, the } \\
\text { water quality is managed by exchanging the filter } \\
\text { regularly. }\end{array}$ & 183 & 98.9 \\
\hline $\begin{array}{l}\text { 13. The food prohibited temporarily before completing } \\
\text { the hazard assessment is not used or cooked. }\end{array}$ & 174 & 94.1 \\
\hline \multicolumn{3}{|l|}{\begin{tabular}{|c|} 
<The cooking process management area $>$ \\
\end{tabular}} \\
\hline $\begin{array}{l}\text { 14. The dishes, cutting board, knife, dishcloth, and } \\
\text { other kitchen utensils are cleaned, sterilized and } \\
\text { disinfected regularly' }\end{array}$ & 152 & 82.2 \\
\hline $\begin{array}{l}\text { 15. The cutting board is used separately for fishes, } \\
\text { meats, vegetables. }\end{array}$ & 167 & 90.3 \\
\hline
\end{tabular}

\begin{tabular}{|c|c|c|}
\hline $\begin{array}{l}\text { 16. Handling foods is performed at the height higher } \\
\text { than } 60 \mathrm{~cm} \text { from the floor. }\end{array}$ & 171 & 92.4 \\
\hline $\begin{array}{l}\text { 17. The food ingredient which is not cooked by heating } \\
\text { is disinfected with chlorine and washed enough. }\end{array}$ & 15 & 8.1 \\
\hline $\begin{array}{l}\text { 18. The frozen food is thawed sanitarily and the thawed } \\
\text { food is used immediately. }\end{array}$ & 160 & 86.5 \\
\hline $\begin{array}{l}\text { 19. The different dishcloth, glove and apron are used for } \\
\text { preparing, cook and cleaning. }\end{array}$ & 36 & 19.5 \\
\hline $\begin{array}{l}\text { 20. The hygiene management is performed such as if the } \\
\text { cooking equipment, food distribution tools, and storage } \\
\text { containers are cleaned, disinfected, and kept. }\end{array}$ & 164 & 88.6 \\
\hline $\begin{array}{l}\text { 21. The cooked foods are managed in order to be } \\
\text { completed the intake. }\end{array}$ & 173 & 93.5 \\
\hline $\begin{array}{l}\text { 22. The appropriate sanitary clothing (sanitary glove, } \\
\text { sanitary apron, etc.) is worn when distributing the } \\
\text { foods. }\end{array}$ & 86 & 46.5 \\
\hline \multicolumn{3}{|c|}{$\begin{array}{l}<\text { The food ingredient storage management area }> \\
\end{array}$} \\
\hline $\begin{array}{l}\text { 23. The foods are managed to meet the preservation and } \\
\text { storage standard when keeping the foods (cold storage: } \\
5^{\circ} \mathrm{Cor} \text { below, refrigeration: }-18^{\circ} \mathrm{C} \text { or below) }\end{array}$ & 100 & 54.1 \\
\hline $\begin{array}{l}\text { 24. The raw material and products that can be spoiled } \\
\text { easily are stored and managed in the refrigerator or } \\
\text { freezer. }\end{array}$ & 136 & 73.5 \\
\hline \multicolumn{3}{|l|}{\begin{tabular}{|c|}
$<$ The other foodservice management area $>$ \\
\end{tabular}} \\
\hline $\begin{array}{l}\text { 25. Thefoods are cooked directly and provided in the } \\
\text { child care center' }\end{array}$ & 183 & 98.9 \\
\hline $\begin{array}{l}\text { 26. Thefoods that have been provided already are not } \\
\text { used again (refers to the foods distributed and provided } \\
\text { to the children on the food tray). }\end{array}$ & 179 & 96.8 \\
\hline $\begin{array}{l}\text { 27. The kitchen and the storage for raw material and } \\
\text { foods are disinfected regularly. }\end{array}$ & 161 & 87.0 \\
\hline \begin{tabular}{|c|} 
Total \\
\end{tabular} & 185 & 100 \\
\hline
\end{tabular}

\section{Comparison of sanitary management scores of family child care center before and after first foodservice management support}

The investigation results to find out if there is any significant difference between the average scores before and after the foodservice management support after performing the first foodservice sanitary management support visit to the family child care center are shown in Table 3. After performing the first visit support, the average score of the overall foodservice sanitary management was raised significantly from 69.70 points (full score of 100 points) to 80.63 points $(p<0.001)$ and the items that showed the significant increase of average score at each item) were 15 out total 27 items $(p<0.05, p<0.01, p<0.001)$. In the average score by total 6 areas, all 6 areas showed significant difference $(p<0.05, p<0.001)$, out of which the highest increase in the average score was shown in the 'cooking process management area $(\mathrm{t}=10.656, p<0.001)$.

Table 3. The comparison of sanitary management before and after the first support

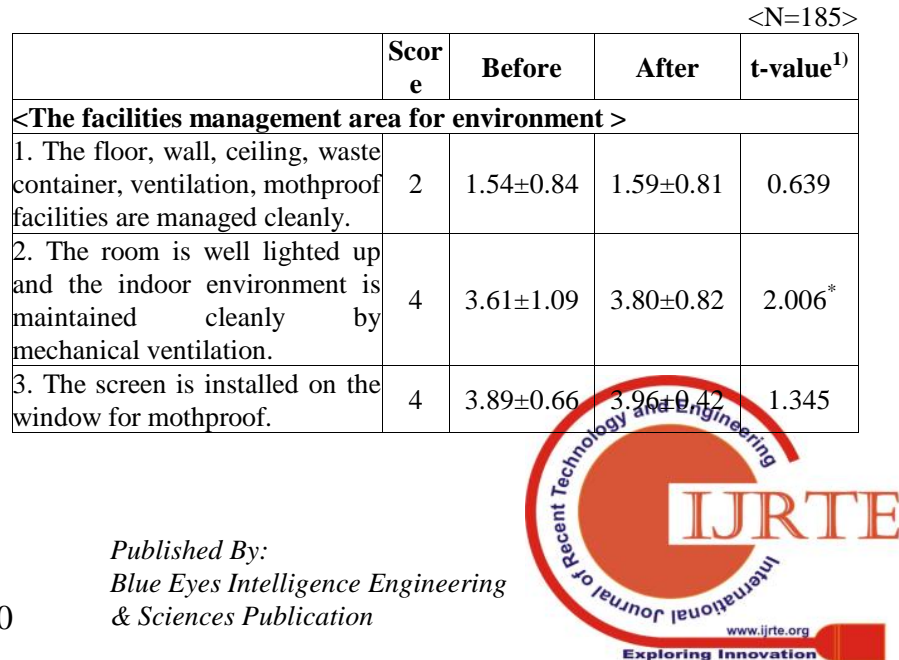




\begin{tabular}{|c|c|c|c|c|}
\hline $\begin{array}{l}\text { 4. The kitchen is equipped to } \\
\text { disinfect the tableware and to } \\
\text { cook sanitarily. }\end{array}$ & 4 & $3.71 \pm 1.03$ & $3.74 \pm 1.00$ & 0.258 \\
\hline \begin{tabular}{|c|} 
Subtotal \\
\end{tabular} & 14 & $12.75 \pm 2.18$ & $13.09 \pm 1.60$ & $2.022^{*}$ \\
\hline \multicolumn{5}{|l|}{$\langle$ The personal hygiene area $\rangle$} \\
\hline $\begin{array}{l}\text { 5. The cook is receiving health } \\
\text { checkup once a year. }\end{array}$ & 4 & $2.37 \pm 1.97$ & $3.52 \pm 1.30$ & $7.211^{* * * *}$ \\
\hline $\begin{array}{l}\text { 6. The cook pays thorough } \\
\text { attention to the personal hygiene. } \\
\text { (including wearing disinfected } \\
\text { garment, sanitary cap and } \\
\text { sanitary glove and cleaning } \\
\text { hands after contaminated work, } \\
\text { etc) }\end{array}$ & 4 & $2.46 \pm 1.67$ & $3.43 \pm 1.27$ & $6.864^{* * * *}$ \\
\hline $\begin{array}{l}\text { 7. The cook doesn't wear the } \\
\text { accessories such as earring, ring, } \\
\text { manicures when cooking. }\end{array}$ & 2 & $1.21 \pm 0.98$ & $1.61 \pm 0.99$ & $4.233^{* * *}$ \\
\hline \begin{tabular}{|c|} 
Subtotal \\
\end{tabular} & 10 & $6.07 \pm 3.15$ & $8.56 \pm 2.42$ & $10.562^{* * * *}$ \\
\hline \multicolumn{5}{|c|}{$\langle$ The food ingredient and raw material management area } \\
\hline $\begin{array}{l}\text { 8. The unauthorized raw material } \\
\text { and food are not used }\end{array}$ & 5 & $3.27 \pm 2.39$ & $4.01 \pm 1.99$ & $3.029^{* *}$ \\
\hline $\begin{array}{l}\text { 9. The spoiled raw material and } \\
\text { food are not used or stored. }\end{array}$ & 5 & $4.67 \pm 1.24$ & $4.75 \pm 1.09$ & 0.654 \\
\hline $\begin{array}{l}\text { 10. The unmarked raw material } \\
\text { and food are not used. }\end{array}$ & 5 & $1.13 \pm 2.09$ & $2.66 \pm 2.50$ & $6.458^{* * *}$ \\
\hline $\begin{array}{l}\text { 11. The raw material or food } \\
\text { expired the self life is not used or } \\
\text { stored for the purpose of } \\
\text { cooking, }\end{array}$ & 5 & $3.32 \pm 2.37$ & $3.41 \pm 2.34$ & 0.350 \\
\hline $\begin{array}{l}\text { 12. In case of using the water } \\
\text { supply system, the water is used } \\
\text { after boiling or in case of using } \\
\text { water purifier, the water quality } \\
\text { is managed by exchanging the } \\
\text { filter regularly. }\end{array}$ & 4 & $3.96 \pm 0.42$ & $3.96 \pm 0.42$ & 0.000 \\
\hline $\begin{array}{l}\text { 13. The food prohibited } \\
\text { temporarily before completing } \\
\text { the hazard assessment is not used } \\
\text { or cooked. }\end{array}$ & 4 & $3.91 \pm 0.59$ & $4.00 \pm 0.00$ & $2.017^{*}$ \\
\hline Subtotal & 28 & $20.26 \pm 4.78$ & $22.79 \pm 5.97$ & $4.357^{* * * *}$ \\
\hline \multicolumn{5}{|c|}{$\langle$ The cooking process management area $\rangle$} \\
\hline $\begin{array}{l}\text { 14. The dishes, cutting board, } \\
\text { knife, dishcloth, and other } \\
\text { kitchen utensils are cleaned, } \\
\text { sterilized and disinfected } \\
\text { regularly' }\end{array}$ & 4 & $2.93 \pm 1.56$ & $3.78 \pm 0.72$ & $8.756^{* * * *}$ \\
\hline $\begin{array}{l}\text { 15. The cutting board is used } \\
\text { separately for fishes, meats, } \\
\text { vegetables. }\end{array}$ & 4 & $3.26 \pm 1.31$ & $3.91 \pm 0.46$ & $6.508^{* * * *}$ \\
\hline $\begin{array}{l}\text { 16. Handling foods is performed } \\
\text { at the height higher than } 60 \mathrm{~cm} \\
\text { from the floor. }\end{array}$ & 2 & $1.85 \pm 0.53$ & $1.89 \pm 0.46$ & 0.852 \\
\hline $\begin{array}{l}\text { 17. The food ingredient which is } \\
\text { not cooked by heating is } \\
\text { disinfected with chlorine and } \\
\text { washed enough. }\end{array}$ & 2 & $0.16 \pm 0.55$ & $0.41 \pm 0.81$ & $3.800^{* * *}$ \\
\hline $\begin{array}{l}\text { 18. The frozen food is thawed } \\
\text { sanitarily and the thawed food is } \\
\text { used immediately. }\end{array}$ & 2 & $1.73 \pm 0.69$ & $1.91 \pm 0.73$ & $2.752^{* *}$ \\
\hline $\begin{array}{l}\text { 19. The different dishcloth, glove } \\
\text { and apron are used for preparing, } \\
\text { cook and cleaning. }\end{array}$ & 2 & $0.40 \pm 0.80$ & $0.92 \pm 1.00$ & $6.015^{* * *}$ \\
\hline $\begin{array}{l}\text { 20. The hygiene management is } \\
\text { performed such as if the cooking } \\
\text { equipment, food distribution } \\
\text { tools, and storage containers are } \\
\text { cleaned, disinfected, and kept. }\end{array}$ & 4 & $1.78 \pm 0.63$ & $1.89 \pm 0.46$ & 1.903 \\
\hline $\begin{array}{l}\text { 21. The cooked foods are } \\
\text { managed in order to be } \\
\text { completed the intake. }\end{array}$ & 4 & $1.87 \pm 0.50$ & $1.87 \pm 0.50$ & 0.000 \\
\hline $\begin{array}{l}\text { 22. The appropriate sanitary } \\
\text { clothing (sanitary glove, sanitary } \\
\text { apron, etc.) is worn when } \\
\text { distributing the foods. }\end{array}$ & 4 & $0.92 \pm 1.00$ & $1.08 \pm 1.00$ & 1.733 \\
\hline Subtotal & 28 & $14.87 \pm 3.42$ & $17.66 \pm 2.65$ & $10.656^{* * * *}$ \\
\hline
\end{tabular}

23. The foods are managed to meet the preservation and storage \begin{tabular}{ll|l|l|l|} 
standard when keeping the 4 & $2.16 \pm 1.99$ & $3.24 \pm 1.59$ & $5.490^{* * *}$
\end{tabular} foods(cold storage: $5^{\circ} \mathrm{C}$ or below refrigeration: $-18^{\circ} \mathrm{C}$ or below)

24. The raw material and \begin{tabular}{|l|l|l|l|l} 
products that can be spoiled & 4 & $2.21 \pm 1.58$ & $3.43 \pm 1.12$ & $11.385^{* * * *}$
\end{tabular} easily are stored and managed in the refrigerator or freezer.

$$
\text { Subtotal }
$$

\begin{tabular}{l|l|l|l|}
8 & $4.42 \pm 2.42$ & $6.66 \pm 1.89$ & $10.055^{\text {*** }}$ \\
\hline
\end{tabular}

<The other foodservice management area>

25. The foods are cooked directly \begin{tabular}{|l|l|l|l} 
and provided in the child care 4 & $3.96 \pm 0.42$ & $4.00 \pm 0.00$ & 1.418
\end{tabular} center'

26. The foods that have been provided already are not used \begin{tabular}{|ll|l|l|l|l} 
again (refers to the foods & 4 & $3.87 \pm 0.71$ & $3.94 \pm 0.51$ & 1.345
\end{tabular} distributed and provided to the children on the food tray).

27. The kitchen and the storage \begin{tabular}{|l|l|l|l|l} 
for raw material and foods are & 4 & $3.48 \pm 1.35$ & $3.94 \pm 0.69$ & $4.229^{* * * *}$
\end{tabular} disinfected regularly.

\begin{tabular}{|c|c|c|c|c|}
\hline Subtotal & 12 & $11.50 \pm 1.72$ & $11.88 \pm 0.86$ & $3.883^{\text {**** }}$ \\
\hline Total & 100 & $69.70 \pm 8.83$ & $80.63 \pm 9.48$ & $13.402^{* * * *}$ \\
\hline
\end{tabular}

1) t-value is absolute value, ${ }^{*} P<0.05,{ }^{* * *} P<0.01,{ }^{* * * *} P<0.001$

\section{Comparison of sanitary management scores before and after second foodservice management support for family child care center}

The results of comparing the difference between the average scores of sanitary management before and after the support after performing the second foodservice sanitary management support for family child care centers are shown in Table 4.the score of overall foodservice sanitary management after performing the second visit support was increased significantly from 80.63 points (full score of 100 points) to 84.68 points $(p<0.001)$ and the items that showed the significant increase of average score at each item) were 15 out total 27 items $(p<0.05, p<0.01, p<0.001)$. The score increase before and after the first foodservice management support was not significant but the items that the score was increased significantly after the second support were 6 such as 'the storage of foods expired the shelf life' $(p<0.05)$, 'perform the food handling work at the height higher than $60 \mathrm{~cm}$ from floor' ( $p<0.001)$, 'wearing correct sanitary glove and sanitary apron when distributing' $(p<0.001)$, etc.

Table 4. The comparison of sanitary management before and after the second support

\begin{tabular}{|c|c|c|c|c|}
\hline & Score & Before & After & t-value $^{1)}$ \\
\hline \multicolumn{5}{|c|}{$\langle$ The facilities management area for environment $\rangle$} \\
\hline $\begin{array}{l}\text { 1. The floor, wall, ceiling, waste } \\
\text { container, ventilation, mothproof } \\
\text { facilities are managed cleanly. }\end{array}$ & 2 & $1.59 \pm 0.81$ & $1.82 \pm 0.57$ & $4.407^{* * * *}$ \\
\hline $\begin{array}{l}\text { 2. The room is well lighted up and } \\
\text { the indoor environment is } \\
\text { maintained cleanly } \\
\text { mechanical ventilation. }\end{array}$ & 4 & $3.80 \pm 0.82$ & $3.96 \pm 0.36$ & $2.511^{*}$ \\
\hline $\begin{array}{l}\text { 3. The screen is installed on the } \\
\text { window for mothproof. }\end{array}$ & 4 & $3.96 \pm 0.42$ & $3.96 \pm 0.42$ & 0.000 \\
\hline $\begin{array}{l}\text { 4. The kitchen is equipped to } \\
\text { disinfect the tableware and to } \\
\text { cook sanitarily. }\end{array}$ & 4 & $3.74 \pm 1.00$ & $3.93 \pm 0.51$ & $3.069^{* * *}$ \\
\hline \begin{tabular}{|c|c} 
Subtotal & \\
\end{tabular} & 14 & $13.09 \pm 1.60$ & $13.67 \pm 0.95$ & $5.464^{* * * *}$ \\
\hline
\end{tabular}




\begin{tabular}{|c|c|c|c|c|}
\hline \multicolumn{5}{|l|}{ <The personal hygiene area> } \\
\hline $\begin{array}{l}\text { 5. The cook is receiving health } \\
\text { checkup once a year. }\end{array}$ & 4 & $3.52 \pm 1.30$ & $3.98 \pm .029$ & $4.856^{* * * *}$ \\
\hline $\begin{array}{l}\text { 6. The cook pays thorough } \\
\text { attention to the personal hygiene. } \\
\text { (including wearing disinfected } \\
\text { garment, sanitary cap and } \\
\text { sanitary glove and cleaning hands } \\
\text { after contaminated work, etc.) }\end{array}$ & 4 & $3.43 \pm 1.27$ & $3.77 \pm 0.76$ & $4.789^{* * * *}$ \\
\hline $\begin{array}{l}\text { 7. The cook doesn't wear the } \\
\text { accessories such as earring, ring, } \\
\text { manicures when cooking. }\end{array}$ & 2 & $1.61 \pm 0.99$ & $1.70 \pm 0.71$ & 1.096 \\
\hline Subtotal & 10 & $8.55 \pm 2.42$ & $9.46 \pm 1.09$ & $5.462^{* * * *}$ \\
\hline \multicolumn{5}{|c|}{ <The food ingredient and raw material management area> } \\
\hline $\begin{array}{l}\text { 8. The unauthorized raw material } \\
\text { and food are not used }\end{array}$ & 5 & $4.01 \pm 1.99$ & $4.37 \pm 1.67$ & $3.050^{* * *}$ \\
\hline $\begin{array}{l}\text { 9. The spoiled raw material and } \\
\text { food are not used or stored. }\end{array}$ & 5 & $4.75 \pm 1.09$ & $4.78 \pm 1.03$ & 0.576 \\
\hline $\begin{array}{l}\text { 10. The unmarked raw material } \\
\text { and food are not used. }\end{array}$ & 5 & $2.66 \pm 2.50$ & $2.86 \pm 2.48$ & $2.363^{*}$ \\
\hline $\begin{array}{l}\text { 11. The raw material or food } \\
\text { expired the self life is not used or } \\
\text { stored for the purpose of cooking' }\end{array}$ & 5 & $3.41 \pm 2.34$ & $3.65 \pm 2.23$ & $2.537^{*}$ \\
\hline $\begin{array}{l}\text { 12. In case of using the water } \\
\text { supply system, the water is used } \\
\text { after boiling or in case of using } \\
\text { water purifier, the water quality is } \\
\text { managed by exchanging the filter } \\
\text { regularly. }\end{array}$ & 4 & $3.96 \pm 0.42$ & $3.98 \pm 0.29$ & 0.576 \\
\hline $\begin{array}{l}\text { 13. The food prohibited } \\
\text { temporarily before completing } \\
\text { the hazard assessment is not used } \\
\text { or cooked. }\end{array}$ & 4 & $4.00 \pm 0.00$ & $4.00 \pm 0.00$ & - \\
\hline Subtotal & 28 & $22.79 \pm 5.97$ & $23.66 \pm 5.21$ & $4.116^{* * * *}$ \\
\hline
\end{tabular}

\section{<The cooking process management area>}

14. The dishes, cutting board, knife, dishcloth, and other

\begin{tabular}{|l|l|l|l|l} 
kitchen utensils are cleaned, 4 & $3.78 \pm 0.72$ & $3.95 \pm 0.39$ & $2.735^{* *}$
\end{tabular}

sterilized regularly'

15. The cutting board is used

\begin{tabular}{|lr|l|l|l} 
separately for fishes, meats, & 4 & $3.91 \pm 0.46$ & $3.96 \pm 0.29$ & 1.640
\end{tabular} vegetables.

16. Handling foods is performe

\begin{tabular}{|l|l|l|l|l}
\hline at the height higher than $60 \mathrm{~cm}$ & 2 & $1.89 \pm 0.46$ & $1.97 \pm 0.26$ & $2.131^{*}$
\end{tabular}

from the floor.

17. The food ingredient which is

\begin{tabular}{|l|l|l|l|l} 
not cooked by heating is \\
disinfected with chlorine and
\end{tabular}

washed enough

18. The frozen food is thawed

\begin{tabular}{|l|l|l|l|l} 
sanitarily and the thawed food is & 2 & $1.91 \pm 0.73$ & $1.96 \pm 0.29$ & 1.000
\end{tabular}

used immediately.

19. The different dishcloth, glove

\begin{tabular}{|l|l|l|l|l}
\hline and apron are used for preparing, & 2 & $0.92 \pm 1.00$ & $0.99 \pm 1.00$ & 0.749
\end{tabular}

cook and cleaning.

20. The hygiene management is

performed such as if the cooking

\begin{tabular}{ll|l|l|l|l} 
equipment, food distribution & 4 & $1.89 \pm 0.46$ & $1.92 \pm 0.39$ & 0.831
\end{tabular}

tools, and storage containers are

cleaned, disinfected, and kept.

21. The cooked foods are

\begin{tabular}{|l|l|l|l|l} 
managed in order to be completed & 4 & $1.87 \pm 0.50$ & $1.92 \pm 0.39$ & $2.261^{*}$
\end{tabular}

the intake.

22. The appropriate sanitary

clothing (sanitary glove, sanitary
apron, etc.) is worn when $\quad 4 \quad$\begin{tabular}{ll|l|l} 
& $1.08 \pm 1.00$ & $1.44 \pm 0.90$ & $5.727^{* * * *}$
\end{tabular}

distributing the foods.

Subtotal

\begin{tabular}{l|l|l|l|}
28 & $17.66 \pm 2.65$ & $18.67 \pm 2.16$ & $6.172^{* * * *}$
\end{tabular}

$<$ The food ingredient storage management area>

23. The foods are managed to

meet the preservation and storage

\begin{tabular}{ll|l|l|l|l} 
standard when keeping the 4 & $3.24 \pm 1.59$ & $3.78 \pm 0.91$ & $5.130^{* * * *}$
\end{tabular}

foods(cold storage: $5^{\circ} \mathrm{C}$ or below,

refrigeration: $-18^{\circ} \mathrm{C}$ or below)

\begin{tabular}{|l|l|l|l|l|l|}
\hline 24. & The raw material and 4 & $3.43 \pm 1.12$ & $3.84 \pm 0.59$ & $5.246^{* * * *}$ \\
\hline
\end{tabular} products that can be spoiled

easily are stored and managed in the refrigerator or freezer.

$$
\text { Subtotal }
$$

\begin{tabular}{l|l|l|l|}
8 & $6.67 \pm 1.88$ & $7.62 \pm 1.05$ & $7.361^{\text {*** }}$ \\
\hline
\end{tabular}

<The other foodservice management area>

25. The foods are cooked directly

\begin{tabular}{ll|l|l} 
and provided in the child care 4 & $4.00 \pm 0.00$ & $4.00 \pm 0.00$
\end{tabular}

center'

26. The foods that have been

provided already are not used

again (refers to the foods $4 \quad 3.94 \pm 0.51 \quad 3.94 \pm 0.51$

distributed and provided to the

children on the food tray).

27. The kitchen and the storage

\begin{tabular}{|l|l|l|l|l} 
for raw material and foods are & 4 & $3.94 \pm 0.69$ & $3.96 \pm 0.42$ & 0.317
\end{tabular}

disinfected regularly.

\begin{tabular}{|c|c|c|c|c|}
\hline Subtotal & 12 & $11.08 \pm 0.86$ & $11.89 \pm 0.65$ & 0.272 \\
\hline Total & 100 & $80.63 \pm 9.48$ & $84.98 \pm 7.10$ & $9.921^{\text {**** }}$ \\
\hline
\end{tabular}

${ }^{1)} \mathrm{t}$-value is absolute value, ${ }^{*} P<0.05,{ }^{* * *} P<0.01,{ }^{* * * *} P<0.001$

\section{DISCUSSION}

This study intended to examine the status of foodservice sanitary management of family child care centers that provide the foodservice to the 20 children or less, and to evaluate the effects of Center's support by comparing how the foodservice sanitary management condition was improved before and after the support of the Center for Children's Foodservice Management. In the foodservice sanitary management status in the family child care centers before receiving the service of the Center for Children's Foodservice Management, the average compliance rate of 'the personal hygiene management area' was $55.7 \%$ showing the lowest compliance rate out of total 6 areas. According to Lee [13], the personal hygiene of the cooks engaged in small day care center was significantly improved in the scores of checklist and simple microorganism test level after receiving the sanitary education. In the research of Lee [14], the cooks who received the sanitary education answered that they do not wear the accessories such as ring, etc. and wear the sanitary glove well when they cook or distribute the foods in the child care center than the cooks who have not received the sanitary education. According to Soon et al. [15], the desirable sanitary education should be leaded to hygiene practices by giving not only the knowledge but also influence on the personal hygiene attitudes. In this study, the scores of the personal hygiene area after receiving first and second support of the Center of Children's Foodservice Management were increased to 8.56 and 9.46 points respectively from 6.07 points (full score of 10 points) showing significant increase in the score. Therefore, to increase the compliance rate of personal hygiene area, the opportunity of sanitary education should be given to the cooks of child care centers continuously.

In this study, the 'food ingredient storage and management area' showed second lowest compliance rate following the personal hygiene management, and particularly, the maintaining the temperature of freezer and refrigerator was shown inappropriate (compliance rate $54.1 \%$ ). In the research of Lee [16], the cooks of family child care centers answered that they comply with the temperatures of the freezer and refrigerator where the food ingredients are stored (3.69 points, $73.8 \%$ ) 
(full score of 5 pints) but they showed the low rate of correct answer (refrigerator $35.6 \%$ and Freezer $31.3 \%$ ) in the sanitary knowledge investigation that finds out specific temperatures [14]. In addition, out of the investigation items, the compliance rate that distinguishing the dishcloth, glove and apron for cooking and cleaning was very low (19.5\%) but it was improved significantly after the first support. Since the children under the 5 years old have weak immune function against the infection, particularly when preparing and distributing the foods in the child care center, the sanitary management of all processes, temperature management, cross-contamination management are very important so that the foods are not contaminated with harmful microbes $[17,18]$. The high microorganism contamination value in the equipment and tools within the kitchen of child care center where the sanitary management is not sufficient was reported [5], and to prevent that, the policy standard and the intervention management are required [17]. Therefore, the service of the Center for Children's Foodservice Management, which performs the education after inspection is made in the actual foodservice site by professional dietitians are deemed to be indispensable for the sanitary foodservice management of the child care centers.

Li et al.[7] reported that the child care centers that participate in the Child and Adult Care Food Program (CACFP) or have specific food preparation policies for foodservice management showed the low contamination level and good overall sanitary management condition compared to the child care centers that did not. Bell et al.[19] also reported that the sanitary management of foodservice and the sanitary education management of the employees were improved compared to before implementing 'Start Right -Eat Right (SRER)', the foodservice management system for child care center in Australia and the compliance rate for SRER was improved in the follow-up than baseline before participation(Improved from 36.6 points (full score of 64 points) to 62.4 points). In this study, the foodservice sanitary management score of the family child care centers after receiving the support of the Center for Children's Foodservice Management was improved before receiving the support. Particularly, judging by that while there were the items that have been improved rapidly after the first visit, there were the items that were improved significantly after receiving the second support than the first support, it needs the continuous sanitary education. Therefore, the family child care centers receiving the benefits from the Center for Children's Foodservice Management, which is operated with the national expenses and the expenses of local government, should be increased and the small child care centers should not be marginalized from the benefits of the Center for Children's Foodservice Management by the large child care centers. Particularly, the management criteria and the program for intervention fit to the small child care center should be provided.

\section{CONCLUSION}

This study intended to examine the foodservice sanitary management status in the family child care centers, which are the small foodservice center, and prepare the foundation so that more family child care centers can received the benefits from the Center for Children's Foodservice Management by evaluating the effects after receiving the service of the Center for Children's Foodservice Management. In the results of this study, the foodservice sanitary management score of the family child care centers were improved constantly after the first and second support compared to before receiving the service of that. Therefore, more family child care centers should receive the support of the Center for Children's Foodservice Management continuously.

\section{ACKNOWLEDGMENT}

The author acknowledge that the data in this study is a part of the Center for Children's Foodservice Management dedicated to small child care center in Cheongju City and express my special thanks to the team leader and members, who made great efforts for site inspection and management, and the directors of child care centers, the member of the Center for Children's Foodservice Management.

\section{REFERENCES}

1. Ministry of Health and Welfare in Korea. 2016. Child Care Statistics. Available:

http://www.kcpi.or.kr/site/hp3/contents/data_n/reference04_1.jsp.

2. K.S. Kwon, J.Y. Park, "A Study of the directors' discourse on the home based child care facilities management" J Korea Early Childhood Educ. 19(3), 1-27, 2012. Available: http://riss.kr/search/detail/DetailView.do?p_mat_type=1a0202e37d52c 72d\&control_no=9e89de805edba885ffe0bdc3ef48d419\#redirect.

3. N. Lu, M.E. Samuels, L. Shi, S.L. Baker, S.H. Glover, J.M. Sanders, "Child day care risks of common infectious diseases revisited" Child Care Health Dev., 30(4), 361-368, 2004. Available: https://doi.org/10.1111/j.1365-2214.2004.00411.x

4. R. Enserink, R. Ypma, G.A. Donker, H.A. Smit, W. van Pelt, "Infectious disease burden related to child day care in the Netherlands" Pediatr. Infect. Dis. J., 32(8), 334-340, 2013. Available: https://www.ncbi.nlm.nih.gov/pubmed/23584578

5. D.M. Staskel, M.E. Briley, L.H. Field, S.S. Barth, "Microbial evaluation of foodservice surfaces in Texas child-care centers" J Am. Diet. Assoc., 107(5), 854-859, $2007 . \quad$ Available: https://doi.org/10.1016/j.jada.2007.02.013

6. C.M. Cosby, C. Costello, W. Morris, B. Haughton, M. Devereaux, F Harte, "Microbiological analysis of food contact surfaces in child care centers" Appl. Environ. Microbiol., 74(22), 6918-6922, 2008 Available: https://doi.org/ 10.1128/AEM.00547-08

7. Y. Li, L.A. Jaykus, S. Cates, K. Wohlgenant, X. Chen, A.M. Fraser, "Hygienic conditions in child-care facilities in North Carolina and South Carolina: an integrated microbial and observational study" Am J Infect. Control, 42(7),781-786, 2014. Available: https://doi.org/10.1016/j.ajic.2014.03.009

8. The Korea Food and Drug Administration. Guideline for Center for Children' Foodservice Management. Ministry of Food and Drug Safety. Cheongju, Korea. pp.42-111, $2016 . \quad$ Available: https://ccfsm.foodnara.go.kr/home/?menuno=164.

9. Ministry of Food and Drug Safety. Press release of MHW,"Our kids' meals are safe: 11 to 15 times higher than the social benefit investment promotion Center for Children's Support Center". Available: http://www.nifds.go.kr/brd/m_21/view.do?seq=7797\&srchFr=\&srchTo $=\&$ srchWord $=\&$ srchTp $=\& i t m \_s e q \_1=0 \& i t m \_s e q \_2=0 \& m u l t i$ itm_seq $=0 \&$ company_cd $=\&$ company_nm $=\&$ page $=8 \overline{7}$

10. Center for Children' Foodservice Management. Homepage of Center for Children' Foodservice Management. Available: https://ccfsm.foodnara.go.kr.

11. Ministry of Food and Drug Safety. Press Release of MHW, "The number of children benefiting from the 17th year of establishment of the CCFSM will increase". Available: 
http://www.mfds.go.kr/brd/m_99/view.do?seq=35281\&srchFr=\&srchT $\mathrm{o}=\& \operatorname{srchWord}=\% \mathrm{EC} \% 96 \% \mathrm{~B} 4 \% \mathrm{~EB} \% \mathrm{~A} 6 \% \mathrm{~B} 0 \% \mathrm{EC} \% 9 \mathrm{D} \% \mathrm{~B} 4 \% \mathrm{EA} \% \mathrm{~B}$ $8 \% 89 \% \mathrm{EC} \% 8 \mathrm{~B} \% 9 \mathrm{D} \% \mathrm{EA} \% \mathrm{~B} 4 \% 80 \% \mathrm{~EB} \% \mathrm{A6} \% \mathrm{AC} \% \mathrm{EC} \% \mathrm{~A} 7 \% 80 \% \mathrm{E}$ $\mathrm{C} \% 9 \mathrm{~B} \% 90 \% \mathrm{EC} \% 84 \% \mathrm{BC} \% \mathrm{ED} \% 84 \% \mathrm{~B} 0 \& \mathrm{srchTp}=0 \& \mathrm{itm} \_s e q \_1=0 \& \mathrm{i}$ tm_seq_2=0\&multi_itm_seq=0\&company_cd=\&company_nm=\&page $=1$.

12. J.E. Lee, “Administrators' Experience of Using Service Provided by Center for Children's Foodservice Management among Home-based Child Care Centers in Seoul" J Korean Diet. Assoc., 23(3), 240-262, 2017. Available: https://doi.org/10.14373/JKDA.2017.23.3.240.

13. J.H. Lee, "An Investigation of factors that influence hygiene practices at a small day care center" J Food Prot., 81(1), 158-164, 2018. Available: https://doi.org/10.4315/0362-028X.JFP-17-163

14. J.E. Lee, "A study on the food hygiene knowledge, attitude, and practice of the home day care center directors and teachers" J Eng. App. Sci., 12 (2,SI), 6173-6179, $2017 . \quad$ Available: http://medwelljournals.com/abstract/?doi=jeasci.2017.6173.6179.

15. J.M. Soon, R. Baines, P. Seaman, "Meta-analysis of food safety training on hand hygiene knowledge and attitudes among food handlers" J Food Prot., 75(4), 793-804. 2012. Available: https://doi.org/10.4315/0362-028X.JFP-11-502

16. J.E. Lee, "An investigation of self-evaluated performance on food service management among directors and teachers of home day care centers" J Eng. App. Sci., 12(7,SI), 8100-8106, 2017. Available: http://medwelljournals.com/abstract/?doi=jeasci.2017.8100.8106

17. S.E. Benjamin Neelon, M.E. Briley, "Position of the American Dietetic Association: Benchmarks for Nutrition in Child Care" J Am Diet. Assoc., 111(4), 607-615, 2011. Available: https://doi.org/ 10.1016/j.jada.2011.02.016.

18. J. Reynolds, L. Rajagopal, "Childcare food handling employees' perceived barriers and motivators to follow food safety practices" Early Childhood Educ. J., 46(5), 477-485, 2018. Available: https://doi.org/ 10.1007/s10643-017-0885-3

19. L.K. Bell, G.A. Hendrie, J. Hartley, R.K. Golley, "Impact of a nutrition award scheme on the food and nutrient intakes of 2- to 4-year-olds attending long day care" Public Health Nutr., 18(14), 2634-2642, 2015. Available: https://doi.org/10.1017/S1368980014003127

\section{AUTHORS PROFILE}

Dr. Joo-Eun Lee is an Associate Professor in Seowon University. And she is a director of Center 3 for children's foodservice management in Cheongju City, Chungbuk, South Korea. She received her Ph.D. in Dep. of Food and Nutrition at Yonsei University in Seoul, Korea in 2008. She worked as a dietitian for food service management of nutrition department at Samsung Medical Center for five years, and her major in detail is food service management and institutional food service. 